\title{
Yuanyuan from There to Here: Perlexity between Beginning and Ending of My Fieldwork
}

\author{
Yuanyuan Chen \\ Hui Institute of Ningxia University, Yinchuan, China \\ Email:634244162@qq.com
}

How to cite this paper: Chen, Y.Y. (2017) Yuanyuan from There to Here: Perlexity between Beginning and Ending of $\mathrm{My}$ Fieldwork. Open Journal of Social Sciences, 5, 282-288.

https://doi.org/10.4236/jss.2017.58023

Received: July 3, 2017

Accepted: August 27, 2017

Published: August 30, 2017

Copyright $\odot 2017$ by author and Scientific Research Publishing Inc. This work is licensed under the Creative Commons Attribution International License (CC BY 4.0).

http://creativecommons.org/licenses/by/4.0/

\begin{abstract}
How to write culture about ourselves? I attempt to re-look at my life and teaching in Cambodia as a Chinese volunteer and try to express my own group. Actually, the work is not more convinced despite the object in the work is also the author. There is, of course, no answer to the question that what the proper way of ethnography writing is. Perlexity between Beginning and Ending of Fieldwork is always there, and the only thing we could do is to provide detailed materials to seek the truth.
\end{abstract}

\section{Keywords}

Experience in Cambodia, Ethnography Writing, Reflections

\section{Introduction}

These two concepts, there and here, stem from the book of Geertz, Clifford. In the book, Works and Lives. The Anthropologist as Author, he discussed four kinds writing patterns and draw a conclusion that, as an anthropologist, the only thing we could do is to seek truth there and seek "function" here. In this easy, primarily, I will introduce my experience in Cambodia, and then I will present my confusions and reflections of ethnography writing.

\section{There: My Experience in Cambodia}

No signal state on my telephone remanded me that I had been in another country. The first greeting, however, is from the border-guard. "Money", he told me in frequently Chinese. "Why?", this is my first reaction. "Tip". "No Tip." I refused without hesitation. It is usual for the border-guard to ask Chinese tourists for tip. There were no worries and anxieties, just like last two times, during this trip. 
Undoubtedly, Cambodia and Chinese teacher volunteer both have special meanings for me. The former is one of countries that I have looked forward to, especially Angkor Wat. The later is the status I have been. Just like the last two trip, individuals in Cambodia are so kind and friendly. There are a substantial number of reasons for me to love this country, e.g. TUK-TUK, hammock, Smile of Angkor.

Graduated in 2014, I came to Phnom Penh as a Chinese teacher volunteer. I still remember the school, Zhonghua International School, as well as the cute children in my classes. The internationals of my students are various, including Chinese, Cambodian and Korean. Smile on their faces, they told me a substantial number of childlike stories. I had always been, actually, in a state of conflict that I was really doubt whether it was a kind of glorious work or not. On one hand, I was teaching them Chinese and substantial number of children had chance to study due to our support. On the other hand, I could not help to thinking about the meaning of Chinese culture and how I were ought to teach them. Just as the old saying said, when god brings the blank space, see that you do not fill it in, but wait. Confronting my lovely students, a group of 5 years old children, it was so hard to choice what could be on the papers. The only thing I confirmed was that I should avoid making too much beautiful impressions of China on them. So what should I do? I could not understand my confusion until I read the book What is Anthropology by Wang Mingming. In conclusion, all my bewilderment was completely derived from the contact of two customs, namely, Us/Not-Us, especially when there was an adult individual in front of the children. Nowadays, anthropology gives me the answer to this question, of course, also brings more confusion.

\section{Here: The Perlexity of Writing}

It is this experience that I have been there urges me to go back there as soon as possible. What I are expected is, from the outside perspective, to re-look at my life and teaching in Cambodia. As a result of previous volunteer, the investigation is relatively easy for me. But when it comes to writing here, it is caught in another dilemma: expression and interpretation seem to make me embarrassed.

Three years ago, I could not yet describe my kind of confusion and hesitation. Should I bring these children so much imagination about China? Chinese snow, Chinese dumplings, Chinese mountains and rivers, Chinese characters, Chinese cuisine and music. In fact, in my heart, there is another voice: China is not so much special, and Cambodian also has its lovely place. Unlike my confusion three years ago, which was just an intuition, but now I ensure that this confusion was an anxiety and reflection from the communicator of the culture.

Currently, I tend to describe the pictures of their lives. Whereas, I am falling into anxiety at the moment starting the project. Later, I met Geertz and WORKS AND LIVES: The Anthropologist as Author. However, It was disappointed to read the book for the purpose of trying to solve my anxiety. And the reason for 
disappointment is due to that it did not give me an answer but not the content itself.

Though there are no answer, I should read more books and finally find a suitable explanation. Geertz thinks that ethnography is not a horse (story), nor a donkey (experimental report), but a mule. As the existence of non-horse donkey, ethnographic writing faces two problems, one is how is the author function manifest in the text; the second is just what is it that the author authors. In WORKS AND LIVES: The Anthropologist as Author, Geertz meticulously distinguish the difference between the author and the writer. However, Geertz only told me that "there is, of course, no single answer to this question, nor can answer be given before the fact, before anthropological authors actually author them" [1]. "the one in which any would-be founders of discursivity must now, and quite probably for some time to come, operate." [2]. Since the standard of ethnographic writing can only come from the ambition of the writer as a "founders of discursivity". Would it cast a "righteous" who thinks that he is a superhero saving the world, however, he is actually a destroyer who fools himself. The argument of "author-function" deeply aroused the anxiety of writing as a beginner.

Since there is no answer, my only choice is to move forward, and hoping to get some answers from the book. Geertz argued that Tristes Tropiques is the author-functional pattern, and Evans-Pritchard is extremely "ethnographic realism". In contract, Marinovsky is a form of experience seeking. However, Benedictine is a kind of cultural irony. Being there /being here represents the conversion of time and space, namely that anthropologists focus on the fieldwork there but the text here. Similarly, it is the purpose to pursuit for the science and reality there but the art of imagination and processing here. In the sight of anthropologists/other, we could draw a conclusion that, in fact, it is a kind of power relationship like west/other or us/not-us. There is no doubt that the gap between the two categories is always wide. Actually, there are entirely different kinds of knowledge in particular historical moments. We may take the illustration that anthropology produced "of-course" Knowledge in the age of positivism, on the contract, anthropologist turned to querying the function but not the truth of text during the period of reflection. The ethical basis and epistemology of anthropology are already are in jeopardy. Whose life is it anyway? Geertz tried to find out a compromise path: "plural lives" of writer and individuals who are as the objects at the same time. What a beautiful picture that anthropologists become mediators who are capable to make both readers and others involved in a conflict come to an understanding of each other. On the perspective of Geertz, it can be expresses as following

"It is to enlarge the possibility of intelligible discourse between people quite different from one another in interest, outlook, wealth, and power, and yet contained in a world where, tumbled as they are into endless connection, it is increasingly difficult to get out of each other's way". [1].

However the anthropologist, for the written about, is absolutely the other. In another word, anthropologists are trying their best to cultivate an ability to keep 
away from themselves but that is impossible. As Franz. Boas putted it, "it is not easy for the anthropologists to liberate themselves from their own cultures, because it is involuntary for us to take the behaviors we acquired from childhood as a natural belongs to all human beings and it should be found all over the world". In fact, it is the thing that is not just hard to do but impossible to do. Man himself are paradoxes for the reason that personal consciousness is "private", but human sociality determines that we have to understand others. How could we think they think? If not, it seems that the interaction between people will become difficult. Helplessly, it is true that the truth is true. These are deeply branded in human cognitive patterns. The existence of self-consciousness of our own ethnicity is due to that there are essentially different others in the world. However, "as long as we have the discrimination of you and me, the two worlds' setbacks will not disappear." Xiong Peiyun put forward the premise and the process of reasoning, but did not say how this cognitive model, us/not-us, were produced and whether could we avoid it? This point, Tzvetan Todorov may be more profound to understand it:

Human beings have always made a distinction between us and the others, and the only alteration is the object to praise. According to Herodotus's Law, they consider themselves the best in the world, and the evaluation of good or bad of others' world is completely based on the distance from themselves. In contrast, according to law of homer, they found the most distant ethnic group is the most happy and envious, but there is completely different scene, in their own country, that the only thing to see is the decline of themselves. Whereas the both judgments are practically fantasy and illusions.

Since the model of us/not-us doomed to casting a shadow up on our lives, what is ought to be the anthropologist's attitude? In addition, what could anthropologists do? Maybe they just overcome a little more impact of prejudice on themselves than ordinary people. Easier said than done. Perhaps it is enough to make anthropologists, standing in the middle of the two worlds, to become the middlemen of communication and understanding between various ethnic groups, although it is also relative for anthropologists.

\section{My Reflections of "The Anthropologist as Author" Presented by Geertz}

Geertz distinguished between a writer and an author, and which is inspired by Michel Foucault. The former is transitive, and they write the society and culture of others; nevertheless, the latter is an activity that I am expressing my opinions and suggestions. In my own perspective, the distinction between the writer and the author can be understood as the distinction between literary texts and ethnographic works. Just as Zhu Guangqian claims that Learning literature is nothing more than "learning writers' experiences concerning vision and sympathy on human beings" [3]. At this point, literature and anthropology are similar. But the two are essentially different. The poet expresses some kind of emotion and 
intelligentsia speak out some kind of anger without any solutions. At best nothing but a mind touched the others'. So there is a significant question that whether anthropology needs to go farther, to think about what kind of person should we be and what is the most essential things of mankind.

Thus, it is necessary to distinguish between literary texts and ethnography. If we see the ethnography as a literary text, they can not avoid that there are difference among literary works in the artistic value. Or we could describe this as the taste of literature:

"Taste of literary is a metaphor, which inspires by the tongue, and it is a very usual thing but also a very difficult thing. Although 'persons all over the world tend to love wonderful things', but in fact, people are eating repeatedly everyday without really enjoying the delicious. It is difficult in the absence of a stable objective standard, but at the same time, it can not be entirely depended on subjective choice." [4].

Back to taste of ethnography, if we see the ethnography as a literary text, who have ability to judge and determine what is pure ethnography taste. The appreciation of literary works can be described as a process of playing or enjoying it. If we choose to play or enjoy an ethnography, it will be a bit outrageous for the reason that all things, persons, as well as their encounters are completely truths but not fictional novels produced for amusing. This is what Geertz says the risk of aestheticism-"and there is, as always when style is attended to and genre underlined, the risk of aestheticism, the possibility that both ethnographers and their audience may come to believe that the value of writing about tatooing or witchcraft exhausts itself in the pleasures of the text. Anthropology as a good read." [5].

Geertz did not tend to avoid talking about the risk, instead, admitted that this risk is worth running. I could not accept this perfunctory explanation without dealing with so many significant problems or his explaining past the reasons. Is the risk really worth running? Where does this risk come from? I would like continue to find the answers.

Primarily, I have no choice to talk about literature which I know little about, as Zhu Guangqian asserted, "You support the poems of Six Dynasties while others appreciate poems in the Tang and Song Dynasties... there is no uniform standard." The so-called elegant or tacky of poem, undoubtedly, depends on the tastes of both authors and readers. We may safely draw a conclusion that there are various determines that contribute to the taste of works, for instance, the result of practice, discipline and punishing of knowledge, or a physical instinct due to long-term experience.

In addition, What about the ethnographic work? Imaging that the two words, ethnography and taste are found in one context, then the first reaction of readers may be weird and illogical. Unlike literature, the pursuit for good taste of ethnography is extremely dangerous. The former is from the intuition, while the latter is out of consciousness. The beauty of the former lies in the "practicality of artfor-art", while the latter permeates the author's will throughout text. We can cri- 
ticize the literature is poor taste, but it is difficult to qualify it as immorality. The distinction between ethnographic text and literary works is that the existence in ethnographic works is not fictional literary images, like the woman Xianglin or man $\mathrm{Q}$, but a living world. There is no doubt that anthropologist do have a moral responsibility for their own works, which is called academic ethics.

It reminds me of an illustration that a mother who announces that I love my child over a neighbor's child, and that is not a shameful thing. Actually, we all do not have to be ashamed of it. But the key is, when the two children playing together, would you give them cakes of the same size. For ethnographic writers, you can not become other, or us and no-us states at the same time. It is similar as the example above. The crux of the problem lies in that the ethnographic authors who tend to describe or express are ought to be true and responsible. No matter what kind of position would you take, your name need to be signed.

In the book of WORKS AND LIVES: The Anthropologist as Author, the first chapter is "Being There: Anthropology and the Scene of Writing". And the last chapter is "Being Here: Whose Life Is It Anyway?". From there to here, this book talking about the stories of fieldwork and writing. In another word, what is anthropology and ought to be? Geertz claimed that the alteration from there to here is not just about the change of time and space, more importantly, the things and values we pursuit for there or here vary enormously. It seems that Geertz, like other postmodernists, deconstructed the traditions of ethnographic writing but not to ensure what it should be. As a result, I still have numerous puzzles about how ethnography should be. There are another experience that I want to share. Participating in a research, as a interviewer, I need to find those who have been criticized that should be rated as the family in poverty, namely that it is my duty to find out families which is in poverty but get no subsidy. When I see the individuals living in the barren land, I subconsciously strive for them, and see it as my mission and responsibility. Just after the end of the matter, I began to reflect on whether I was rational at that time. What if I do insist in the things which is self-righteous but very absurd thing? After all, there are so much selfrighteous compassion in the world and it can easily get power just due to that it seems to be justice. What is worse, this so-called feelings are often very noble and deceptive. I am so glad that I was insisting in an valuable thing. Afterwards, I thought a lot. I remind myself that try not to let the emotions exercise too much impact on me, and think twice. When it comes to the example of charities, Quan lin, a famous hostess, declared that there some disciplines in my charitable organization: when we can not decide which family the rescue should be given to, then we need the standard that the person who is involved in the investigation, does not make the final conclusion. And the only thing they can do is to provide detailed materials. Similarly, the person who made the final decision would never go to the field investigation. Once you had gone to the field, you would find that the final decision is really hard. This illustration brings me a lot of inspired views that being there and being here are completely two kinds of various even opposite works, though anthropologists describe or express in their 
ethnography based on their fieldwork.

\section{Conclusion}

In this easy, I would like to present my experience of Chinese Volunteer teacher in Cambodia and the perlexity of writing the culture of this group. Generally, it seems that the only solution to the Dilemma of Ethnographic Writing is that we seek truth there and seek "function" here. Whereas, I argue that the risk that we see the ethnography as a literary text worth running. And my argument is that being there and being here are completely opposite works, although we could seek truth there but what we seek here is far away clear.

\section{References}

[1] Geertz, C. (1988) Works and Lives: The Anthropologist as Author. Stanford: Stanford University Press, 147.

[2] Geertz, C. (1988) Works and Lives: The Anthropologist as Author. Stanford: Stanford University Press, 148.

[3] Zhu, G.Q. (2013) Talking about Literature. Beijing: Beijing University Press, 3.

[4] Zhu, G.Q. (2013) Talking about Literature. Beijing: Beijing University Press, 26.

[5] Geertz, C. (1988) Works and Lives: The Anthropologist as Author. Stanford: Stanford University Press, 142.

Submit or recommend next manuscript to SCIRP and we will provide best service for you:

Accepting pre-submission inquiries through Email, Facebook, LinkedIn, Twitter, etc. A wide selection of journals (inclusive of 9 subjects, more than 200 journals)

Providing 24-hour high-quality service

User-friendly online submission system

Fair and swift peer-review system

Efficient typesetting and proofreading procedure

Display of the result of downloads and visits, as well as the number of cited articles

Maximum dissemination of your research work

Submit your manuscript at: http://papersubmission.scirp.org/

Or contact jss@scirp.org 